\title{
Self-mutilation, multiculturalism and hybridity. Herodotos on the Karians in Egypt (Hdt. 2.61.2)
}

Liviu Mihail lancu

\section{Q OpenEdition \\ 12 Journals}

Electronic version

URL: http://journals.openedition.org/anatoliaantiqua/441

DOI: 10.4000/anatoliaantiqua.441

\section{Publisher}

IFEA

\section{Printed version}

Date of publication: 1 May 2017

Number of pages: $57-67$

ISBN: 978-2-36245-066-2

ISSN: 1018-1946

\section{Electronic reference}

Liviu Mihail lancu, « Self-mutilation, multiculturalism and hybridity. Herodotos on the Karians in Egypt (Hdt. 2.61.2) », Anatolia Antiqua [Online], XXV | 2017, Online since 01 May 2019, connection on 21 December 2020. URL : http://journals.openedition.org/anatoliaantiqua/441 ; DOI : https://doi.org/ 10.4000/anatoliaantiqua.441 


\section{ANATOLIA ANTIQUA ESKI ANADOLU}

\section{XXV}

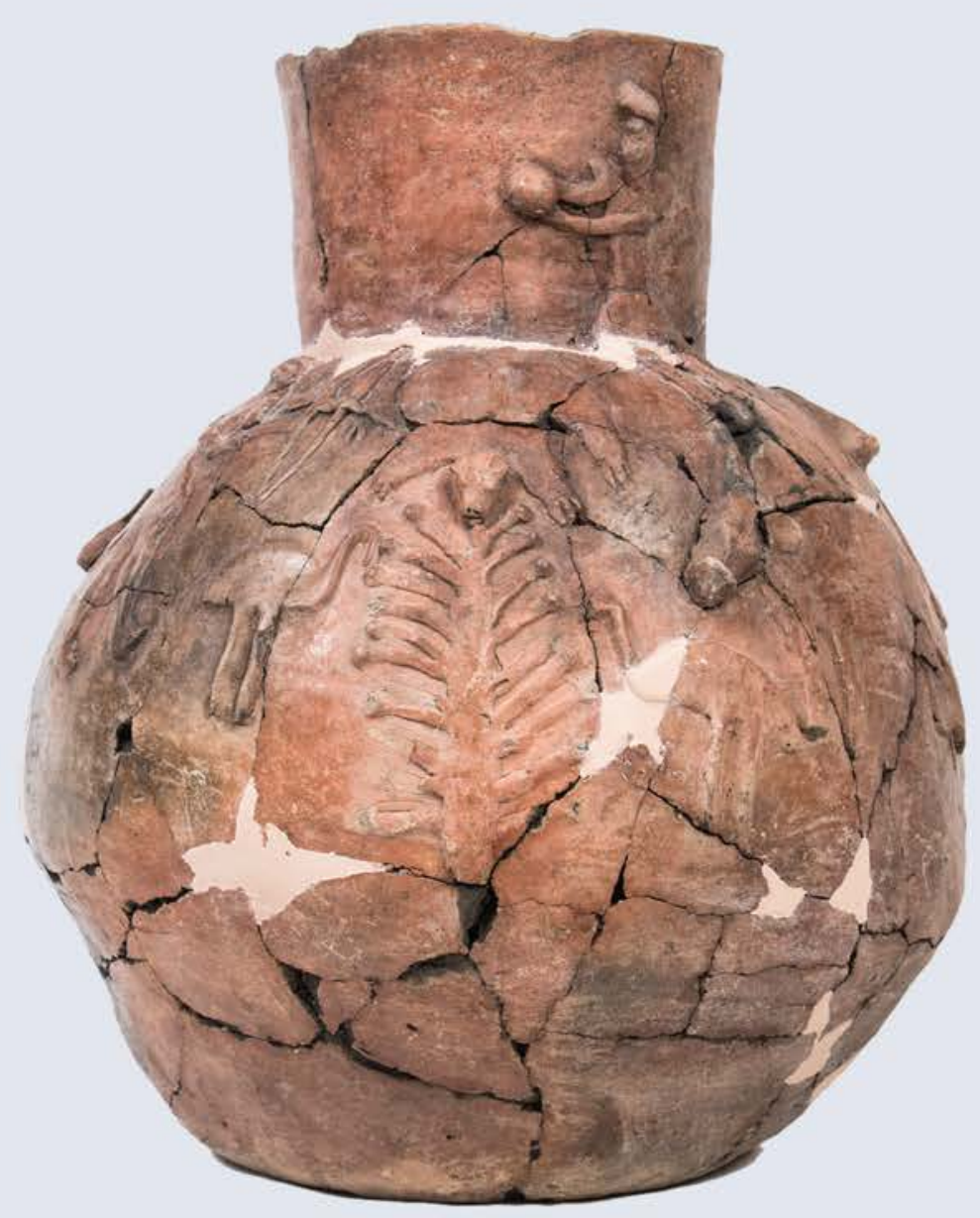

INSTITUT FRANÇAIS D'ETUDES ANATOLIENNES GEORGES-DUMEZIL

CNRS USR 3131

DE BOCCARD 


\section{TABLE DES MATIERES}

N. Pınar ÖZGÜNER et Geoffrey D. SUMMERS

The Çevre Kale Fortress and the outer enclosure on the Karacadağ at Yaraşl1

Abuzer KIZIL et Asil YAMAN

A group of transport amphorae from the territorium of Ceramus: Typological observations

Tülin TAN

The hellenistic tumulus of Eşenköy in NW Turkey

Emre TAŞTEMÜR

Glass pendants in Tekirdağ and Edirne Museums

Liviu Mihail IANCU

Self-mutilation, multiculturalism and hybridity. Herodotos on the Karians in Egypt (Hdt. 2.61.2) .....

\section{CHRONIQUES DES TRAVAUX ARCHEOLOGIQUES EN TURQUIE 2016}

Erhan BIÇAKÇI, Martin GODON et Ali Metin BÜYÜKKARAKAYA, Korhan ERTURAÇ, Catherine KUZUCUOĞLU, Yasin Gökhan ÇAKAN, Alice VINET

Les fouilles de Tepecik-Çiftlik et les activités du programme Melendiz préhistorique, campagne 2016

Çiğdem MANER

Preliminary report on the forth season of the Konya-Ereğli Survey (KEYAR) 2016

Sami PATACI et Ergün LAFLI

Field surveys in Ardahan in 2016

Erkan KONYAR, Bülent GENÇ, Can AVCI et Armağan TAN

The Van Tušpa Excavations 2015-2016

Martin SEYER, Alexandra DOLEA, Kathrin KUGLER, Helmut BRÜCKNER et Friederike STOCK The excavation at Limyra/Lycia 2016: Preliminary report

Abuzer KIZIL, Koray KONUK, Sönmez ALEMDAR, Laurent CAPDETREY, Raymond DESCAT, Didier LAROCHE, Enora LE QUERE, Francis PROST et Baptiste VERGNAUD

Eurômos : rapport préliminaire sur les travaux réalisés en 2016

O. HENRY et D. LÖWENBORG, Fr. MARCHAND-BEAULIEU, G. TUCKER, A. FREJMAN,

A. LAMESA, Chr. BOST, B. VERGNAUD, I. STOJANOVITC, N. CARLESS-UNWINN,

N. SCHIBILLE, Ö.D. ÇAKMAKLI, E. ANDERSSON

Labraunda 2016 


\section{Liviu Mihail IANCU*}

\section{SELF-MUTILATION, MULTICULTURALISM AND HYBRIDITY. HERODOTOS ON THE KARIANS IN EGYPT (HDT. 2.61.2)}

\section{INTRODUCTION}

The small number of sources which provide sure evidence for the existence of Greek mercenaries in the Archaic age brought a continuous and powerful appeal for the discovery in the most obscure testimonies and through the most speculative constructions of new soldiers of fortune, besides those whose paid military activities are already known for certain. Issues like the social status of mercenaries, both in their home communities and in the foreign polities where they served, their role in the international relations of the time or their significance for the economic exchanges in the Eastern Mediterranean are only exceptionally investigated by a few authors ${ }^{1}$. Thus, the attention paid to those fragments which might provide clues about the beliefs, the rituals and the cultural habitus of the already attested mercenaries is low.

Herodotos' account of the Ionians and Karians dwelling in Egypt from the beginning of Psammetichos' I reign is the richest source in such mostly neglected fragments. In a previous article where I examined Hdt. 3.11, I tried to demonstrate that the slaughter of Phanes' children, an illustrious deserter from the Saite army, and the consumption of their blood, mixed with wine and water, by his former comrades, might bring more information on the mercenaries than the simple interpretation that have wanted to revenge themselves through an extreme sacrifice. On the contrary, I stated that there are actually enough reasons to consider the dreadful ritual as the action meant to seal a strong oath that should have dismissed any suspicions of further treason among the various groups of mercenaries in the Pharaoh's army, before the decisive battle of Pelusion ${ }^{2}$.

Similarly, this time I think that the ritual of the Karians in Egypt, of slashing their foreheads with knives during a religious feast of Osiris, depicted in Hdt. 2.61.2, might provide more data on the intercultural contacts between the Aegean mercenaries and other ethnic groups in the Saite kingdom than those extracted until now by the classical, egyptological and biblical historiography.

\section{HDT. 2.61 - DESCRIPTION, CONTEXT, INTERPRETATIONS}

In his long ethnographic excursus on Egypt (2.1-98), Herodotos gave also a short description of the country's main religious festivals, dedicated to the patron deities of the towns of Bubastis, Busiris, Sais, Heliopolis, Buto and Papremis (Hdt. 2.58-63).

On the festival of Osiris and Isis in Bubastis, which he also described in 2.40 , referring to the sacrifice of oxen performed with this occasion, Herodotos stopped only to underscore the great number of participants and their intense manifestations of grief, as they were required by the gods' cult. Nevertheless, Herodotos added also an interesting remark on the Karians who also took part to the religious ceremony: in addition to the Egyptians, they were slashing their foreheads with knives, making thus their distinct ethnicity obvious.

[1] This is what they do there; I have already described how they keep the feast of Isis at Busiris. There, after the sacrifice, all the men and women lament, in countless numbers; but it is not pious for me to say who it is for whom they lament.

*) Center for Comparative History of Ancient Societies, University of Bucharest, liviu.iancu@drd.unibuc.ro

1) E.g. Kaplan 2002 for social status, Agut-Labordère 2012 for the role played in the international relations, van Wees 2013 for the impact on the evolution of Aegean economy.

2) Iancu 2015 . 
[2] Karians who live in Egypt do even more than this, inasmuch as they cut their foreheads with knives; and by this they show that they are foreigners and not Egyptians ${ }^{3}$.

The festival described by Herodotos is doubtless one of the many celebrations that Egyptians dedicated to the regenerative force of nature, metaphorically embodied in the myth of Osiris' death and resurrection, Osiris being the king of the Netherworld and the most important deity in the local pantheon at the middle of the first millennium B.C.

Consequently, the rituals described probably quite exactly in 2.40 and 2.61 by Herodotos, who eye witnessed them somewhere in the second or the third quarter of the $5^{\text {th }}$ century B.C. ${ }^{4}$, might be understood as displaying typical elements of mourning and expressing grief, common to those performed at the private funerary events ${ }^{5}$.

The information that drew my attention, as it had drawn also that of Herodotos, is the extreme manifestation of grief performed in that context only by the Karians which were taking part to the celebration alongside the Egyptians.

This short digression might be explained only by Herodotos' explicit inclination to presenting "wonders"6, a category that encompasses not only impressive monuments and uncommon natural phenomena and physical features, but also ethnographic curiosities $^{7}$. The digression in 2.61.2 is indeed of great interest as it tackles a custom of the Karians, who were a well known population to Herodotos, given the fact that he came from Halikarnassos and that he himself might have had Karian origins. Did Herodotos know this custom as being performed also by the Karians of Anatolia and just here manage to tell it for those unaccustomed with Karia, or was he truly surprised by such a manifestation found only in Egypt?

There are some clues which support the second hypothesis. Firstly, in his ethnographic digression on Karians in 1.171-172, Herodotos tells nothing about this custom, although it was at least as strange as the Kaunians' ritual to strike the air with their spears, in order to cast out the foreign gods (1.172.2). Undoubtedly, someone might say that the information on the Karians' way of slashing their foreheads, by its own nature, was not appropriate to be added in the excursus on the origin of the Karians, in the same way the information on the Karian provenance of the so-called Ionian chiton is not included in 1.171-172, but it is latter added in 5.88.1.

Nevertheless, the second clue is far more convincing. The use of the grammatical structure öбor + a masculine noun in genitive plural (ö $\sigma o r ~ \delta \grave{\varepsilon}$

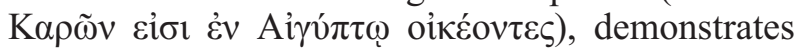
that the custom is attributed exclusively to a certain part of the Karians, respectively only to those living in Egypt ${ }^{8}$.

Such a narrow attribution, as well as the manifest surprise of Herodotos towards the Karians' gashing of their own bodies - surprise that in fact determined the historian to write about it - should have produced the same reaction to the modern commentators of Herodotos' narrative, followed by the natural consequence of conducting more profound investigations on this particular fragment ${ }^{9}$.

Instead of this, both How and Wells in 1912, and Lloyd in 1976 (as well as in his follow up in 2007) confine themselves to mentioning that these Karians are descendents of those referred to afterwards, in 2.152-154, and to providing analogous examples: How and Wells show exclusively biblical parallels

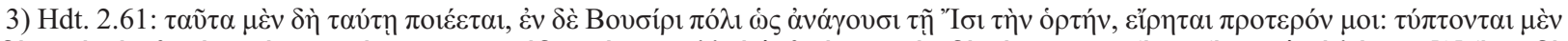

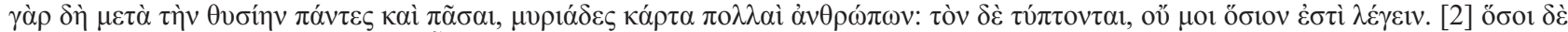

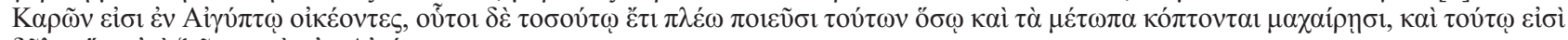

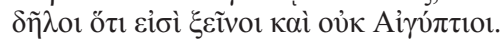

4) Lloyd 1975: 61-68; 2007: 226-227.

5) The testimony on the ritual dedicated to Osiris might be compared in this wise with the description of Egyptian private mourning practices in 2.85 . The chest beating as a manifestation of grief is referred to in both fragments with the same term - the verb $\tau$ tu $\pi \tau \omega$, in middle voice. On the Egyptian festival described by Herodotos, see Lloyd 1976: 276-279; 2007: 278.

6) Hdt. 1.1, 2.35, 4.30, with Vignolo Munson 2001: 232-234, and 2007: 234-235.

7) There are many similar digressions, whose extent depends on the number of strange customs and the quantity of details Herodotos possessed. Cf. Hdt. 1.57 (digression on the Pelasgian language, in the account of Kroisos' embassies to mainland Greece), 1.74 .5 (on the ways the Lydians and the Medes took oaths, in the review of Kroisos' reasons to start the attack in Kappadokia), 3.98-106 (on India, in the review of the tribute and gifts received by Darius), 4.93-96 (on the customs of the Getai, in the account of Darius' Scythian campaign) etc. On the relationship between 'wonders' and digressions, see Hartog 1988: 230-237, especially, 233-234. On the ethnographic dimension of Herodotos' work, see Vignolo Munson 2001.

8) I list here cases of using the same grammatical structure by Herodotos, for the same purpose of defining a smaller group within a greater one, through a specific situation or action: Hdt. 1.174.1, 2.108.4, 4.202.2, 5.72.2, 5.94.2, 5.101.2.

9) On the epistemologic consequences that a thing catalogued as thauma should have, respectively the need of searching for explanations, see Vignolo Munson 2001: 233-234. 
(1 Kings 18:28; Lev. 19:28), without any hypotheses on the origins of the custom, while Lloyd, following authors such as Cumont ${ }^{10}$, with outdated opinions on Attis' cult, interprets the Karian burial custom as a transposition of Attis' ecstatic rituals onto the festival dedicated to Osiris. Both commentaries state the Karians are the first and only ones to introduce such a violent manifestation in Osiris' cult ${ }^{11}$.

Hdt. 2.61.2 drew not only those commentators attention, but also that of McAnally, who devoted an entire study to it. He is integrating into the discussion the observations Martin and Nicholls made on two funerary Karian stelai from Memphis dated in the second half of the $6^{\text {th }}$ century B.C. On these stelai, in typically Aegean prothesis scenes, male characters were depicted as probably lacerating their faces using sharp blades or weapons ${ }^{12}$. McAnnaly drew the conclusion that the action in Hdt. 2.61.2 is in fact a typical manner of expressing grief in funerary contexts of those Karians living in Egypt, both in private and public situations ${ }^{13}$. Starting from this point and stating without any arguments that "there is no evidence that this funerary practice occurred in Karia, suggesting that it, in fact, occurred only in Egypt "14, McAnally proposes the interesting, yet unconvincingly supported idea ${ }^{15}$, that the Karian slashing of their foreheads was a ritual having nothing in common with Anatolia. He explained the custom by an independent development occurring in Egypt, as a Karian means of expressing a foreign identity, different to that of the majority. He brings no arguments besides some inappropriate studies regarding self-inflicted violence and a much too optimistic interpretation of Herodotos' text, in my opinion $^{16}$.

\section{SLASHING THE FOREHEAD AS A FUNERARY RITUAL. HISTORICAL AND ANTHROPOLOGICAL PARALLELS}

Making gashes onto the cranial skin is a funerary custom of great perenniality, despite its violence that frequently determined its banishment throughout ages, both by the political authorities and the representatives of official religions. It was performed during private burials, as well as in the context of religious public ceremonies that reproduced the funerary practices and were deemed to express a profound feeling of grief ${ }^{17}$.

The custom is practiced even nowadays in the Middle East by the Shiites who commemorate the death of the Imam Hussein ibn Ali, the son of the Prophet's cousin, executed by his Umayyad opponents in 680 A.D. Mainly at his execution site, in Karbala, Irak, but also in Iran, Pakistan, India and Indonesia, during the Day of Ashura, Shi'a men are slashing their heads' skin with swords or knives, in a practice called tatbir or qameh-zani and talwar-zani ${ }^{18}$. Thus they express their grief for the cruel death of Hussein and his followers and try to identify through pain with their religious hero. Although the practice gained much in popularity during the Safavid dynasty

10) Cumont 1896, a work markedly influenced by eurocentric stereotypes on the East - Roller 1999: 20-21. The other modern reference used by Lloyd is Strathmann 1950, that mostly has the same flaws..

11) How and Wells 1912: 196; Lloyd 1976: 279-280; 2007: 278-279.

12) London BM 67235 and Berlin ÄM 19553 (24139), with commentaries by Martin and Nicholls 1978: 73-74. Despite these researchers' circumspection and the observations in Miller 1997: 207 and van Wees 1998: 20 regarding the Greek representations of flywhisks used against insects in mourning scenes, I think this interpretation does not suit the images on the two stelai. Vittmann 2003: 171 does not recognise at all the same ritual in Hdt. 2.61.2 and in the two Karian funerary stelai.

13) McAnally 2016: 185-187.

14) McAnally 2016: 187

15) All the more unconvincingly supported as McAnally did not feel the need to contradict Lloyd's hypothesis of the Anatolian origin of the custom, although he cited him elsewhere.

16) McAnally 2016: 184-189. McAnally suggests that Herodotos' words are pointing to a conscious intention of those Karians living in Egypt to mark their different identity through such an action (184), although in fact the Greek historian just made a notice regarding a distinctive feature of the two communities. I think we cannot draw a safe conclusion whether the Karians' manifestation had the intention suggested by McAnally. In my opinion, a safer interpretation is that both ethnic groups taking part to the festival in Busiris were performing their own mourning rituals, without any specific intention to show their distinctive identity.

17) The custom evolved most probably from its initial use in private funeral ceremonies to being a token of grief in general, especially in festivals dedicated to deceased gods. The same evolution is attested for the placing of earth and dust on one's head - Jastrow 1899: 141

18) These are the Arabic, respectively Persian specific terms for the practice, which refers to the special type of weapons used for this custom (which demonstrates that efforts made in McAnally 2016: 181-184, to prove that machaira mentioned by Herodotos was in fact a drepanon - typical Karian combat weapon, see Hdt. 7.93 - are useless: there is no need to use offensive combat weapons in the performance of funerary customs). Besides those slashing their head skin, there are also mourners which hit their back with chains and whips that have blades attached, custom called zanjeer-zani (zanjeer meaning 'chain'). The greatest part of them just beat their chest (sineh-zani) like the Egyptians of Hdt. 2.61.1. 
of Iran ( $16^{\text {th }}-17^{\text {th }}$ centuries A.D. $)$, it was first attested in the $10^{\text {th }}$ century A.D. as typical to the Iranian Buyid realm ${ }^{19}$.

A similar custom is previously mentioned, in the $6^{\text {th }}-10^{\text {th }}$ century A.D. in the Zoroastrian Iran and Central Asia, this time in the memory of the legendary prince Siavash, who suffered mostly the same fate as Hussein ibn Ali, as well as in private funerary ceremonies $^{20}$. Despite interdicts issued by Zoroastrian, Buddhist and Shi'a high priests, then, as like as nowadays, the custom never ceased to be performed, sometimes even with the participation of low status religious ministers ${ }^{21}$.

The aforementioned parallels might be of great use for the thorough understanding of the funerary nature of the practice noticed by Herodotos and might also provide a hint for searching the origins of the custom in the Middle East. Nonetheless, in order to clearly establish the origins of the Karians' action described by Herodotos, we should carefully investigate the funerary practices of the Eastern Mediterranean peoples in the Archaic age and even before it.

The Egyptian provenance should not be discarded from the start without a short discussion. Although Herodotos implies by the very structure of 2.61 that the Egyptians did not cut their skin, he theoretically might have not been the best connoisseur of the evolution of Egyptian funerary practices. Moreover, the practices described in 2.61 and 2.85 (beating the chest, showing the breasts by women, daubing the faces with dust or mud) might not draw the full picture of the Egyptian funerary ritual before and after the embalming.

Egyptian and other sources mention indeed some other expressions of grief in funerary contexts, such as falling to the ground, getting the hands to the head, tearing out the hair, beating and squeezing someone's own breasts and many others ${ }^{22}$. Nonetheless, there are no proofs for slashing someone's own forehead in Egypt $^{23}$ and even though the situation of Egyptian funerary archaeology is far from being clear $^{24}$, available sources at this moment suggest that the hypothesis of an Egyptian origin for the custom is untenable.

Secondly, the roots of the custom might have been tracked back to the Aegean-Anatolian area. Unfortunately, there are almost no data on the Anatolian Karian rituals that accompanied a burial or a manifestation of grief, so that it is difficult to draw any conclusion. Until now, there are no literary sources, inscriptions or artefacts which might sustain an autochthonous Karian origin for the custom signalled by Herodotos ${ }^{25}$.

19) Daryaee and Malekzadeh 2014: 61-62.

20) Daryaee and Malekzadeh 2014: 58-61.

21) Daryaee and Malekzadeh 2014: 59-62.

22) The Old Kingdom: The Pyramid Texts 532 (\$1280-1282) - falling to the ground, getting the hands to the head, squeezing the breasts; The Middle Kingdom: The Coffin Texts 640 - cutting the hair; The Second Intermediate Period: Rishi sarcophagus, tomb CC64 in Thebes - Metropolitan Museum 14.10.1 - barren chest, tearing out the hair, putting dust upon the head; The New Kingdom: the mourners' relief from Horemheb's tomb in Memphis - falling to the ground, getting the hands to the head; the Brooklyn 37.31E relief - falling to the ground, putting dust upon the head, getting the hands to the head and tearing out the hair; the mourners' scene from the Ameneminet's tomb, TT 277 in Thebes, and the funerary procession scene from the Khonsu-em-heb scene in Luxor - unveiling the breasts, rising the hands and eventually getting them to the head, tightening the hair with white pieces of cloth, falling to the earth, beating the chest; the Papyrus of Ani and the Papyrus of Nu mention the tearing out of the hair; The Third Intermediate Period - the beginning of the Saite dynasty: Cleveland Museum of Art 1951.282 funerary relief - getting the hands to the head, tearing out the hair, beating the chest. Greek sources, other than Herodotos: Diod. Sic. 1.91.1; Plut. De Is. et. Os. 14 - the same manifestations as those in Herodotos and additionally the cutting of locks of hair. Cf. Hays 2011: 69-70 and Jastrow 1899: 145-146.

23) A unique late reference of a Christian writer mentions cutting the shoulders as a ritual for Osiris - Firm. Mat., Err. prof. rel. 2. The profound ideological bias of the source, as well as the great span of time between the celebrations mentioned by Herodotos and those narrated by Firmicus Maternus, especially given the fact this is the only reference of this kind, render it irrelevant for the discussion.

24) Quirke 2015: 201-205.

25) A discovery that might be associated with such an extreme manifestation of grief is that of a curved iron weapon, $38 \mathrm{~cm}$ length, found in a late Geometric common grave near Mylasa, described by the researchers who published the tomb as a 'knife' - Arslan and Kiz1l 2007: 90-91, fig. 11. There is not even a single element that might point, however, to its use in the way described by Herodotos. Moreover, such type of curved knives could be easily associated with the typical Karian combat weapons mentioned in Hdt. 7.93. Other tombs of the Late Bronze Age and Early Iron Age located in Karia, which also displayed knives, had spears at the same time - Carstens 2008: 61-62, 76-77, 85. For Karian burials of later time (beginning with the $6^{\text {th }}$ century B.C.), of great diversity, but providing no clues for an autochthonous origin of the custom, see Henry 2009.

The Karian origin of slashing one's forehead is maintained by Ballesteros Pastor 2003: 214-215. Starting from Laumonier's work in 1958 on Karian cults, he states that the bloody rituals in Hdt. 2.61.2 and 3.11.2-3 are typical to the cult of Zeus Karios, god mentioned by Herodotos, who can be equated with the better known Zeus Stratios. Moreover, Ballesteros Pastor draws a relationship between the alleged practices for Zeus Stratios and the wounds made on their arms and legs by the priests of the Kappadokian goddess Ma (interpreted as Bellona in Rome), so that he launches the hypothesis that both cultic manifestations derive from ancient Anatolian traditions. None 
The investigation of the Anatolian Bronze Age funerary rituals or of those of the neighbouring Anatolian populations in the Iron Age does not bring any useful parallels, as they are also scarcely known ${ }^{26}$. Thus, the broadest knowledge available at the moment is that of the funerary practices of the Archaic Greeks, with whom the Karians had close relations, both in Asia Minor and in Egypt, where they served together as mercenaries (Hdt. 2.152, $2.163,3.11)$.

The exaggerated gestures for displaying grief were daunted in Greece, especially in the case of men, while the main role in the mourning of the deceased was attributed to women. The violence of women's mourning rituals varies from tearing out their hair and ripping apart their clothes to scratching their faces and their chests. The last custom, the closest to the Karian slashing of one's forehead, had a short-lived popularity: after a remarkable start at the middle of the $7^{\text {th }}$ century B.C., it is performed less frequently in the following decades, registered once again some greater popularity at the end of the same century and the beginning of the next one, disappearing in the end in the context of the sumptuary laws drafted in the first years of the $6^{\text {th }}$ century B.C. While the origins of this type of laceration are presumed to be Oriental, it seems that it spread as an additional means to highlight the significance and the high social status of the deceased. Probably this is also the reason of its banishment during the egalitarian rise of the $6^{\text {th }}$ century B.C. ${ }^{27}$.

While there are no clues for the slashing the forehead as a mourning ritual in the Aegean-Anatolian area, the practice was associated with the ecstatic rituals performed in the cult of Attis, the follower of the Phrygian Mother of Gods or Kybele. This interpretation is grounded on the Roman information regarding the bloody rituals made by the Galli for her and her attendant. Thus, on the $24^{\text {th }}$ of March, dies sanguinis, the high priest, Archigallus, cut his forearms, dedicating his blood to the deities, while members of the lower clergy gashed their bodies as well, using sharp potsherds and knives, or flagellated themselves, in the rhythm of wild music and dances, splashing the holy altar in order to support the resurrection of the god ${ }^{28}$. When the goddess Atargatis, the Syrian equivalent of Kybele, was celebrated in Hierapolis, young men, driven by frenzy, publicly emasculated themselves as well ${ }^{29}$.

This parallel, interesting for certain, is not valid at a closer look.

Firstly, an important difference should be noted between the two ritualistic expressions. While the Karians were slashing their foreheads with their knives, the worshipers of Kybele and Attis inflicted wounds to their own forearms, backs and genitals. There is as well a great possibility that other marked difference separated the two customs, although we might never have a confirmation of this hypothesis given the fact that our sources are not as exact as the anthropologists' journals: while Kybele's priests and worshipers gashed and flagellated themselves with the purpose of collecting and dedicating reproductive substances and organs like blood and genitals ${ }^{30}$, in a frenetic atmosphere that in reality excluded pain, the Karians' slashing of their foreheads seems not to have had any relation with the collection of blood, its purpose being instead to display the grief produced by the god's death through a painful action which might be listed in the same category with the chest beating or the tearing out of the hair.

I think this substantial difference between the two practices, similar at the first sight, yet distinct both in action and in scope, might be spotted in the West Semitic cultural area, too. There we find on the one hand the slashing of the skin of the face and the upper body, as a mourning ritual, typologically close to shaving the hair (Deut. 14:1; Lev. 19:27-28; Lev. 21:5), while on the other hand the gushing of its own blood, in an atmosphere of frenetic songs and dances, is attested as a way of invoking a deity and asking for its support (1 Kings 18:28, invocation

of Ballesteros Pastor's premises is grounded on references to ancient sources, so that the whole construction remains a speculation. See Iancu 2015 for a more plausible explanation for the slaughter in Hdt. 3.11 - that of sealing an oath. As regarding Ma, besides the late Roman narratives, it seems that she might be one of the Anatolian goddesses whose cults started displaying bloody rituals in a later period than the Archaic age (Lucan. Phars. 1.565-6; Tib. 1.6.43-49; Verg. Aen. 8.703), probably due to influences from similar Syrian deities.

26) See e.g. Bryce 1986: 127-129 on the sheer number of sources on the Lykian funerary customs and the strangest mourning ritual in Lycia - the dressing of men in women clothes.

27) van Wees 1998: especially 19-41. See also Haland 2014: 212-215. The evidences reviewed by Schmidt 1994: 174 do not refer to cuts made onto the cranial skin by men using sharp objects, but to scratches like those described by van Wees.

28) On the bloody rituals dedicated to Attis and Kybele or her Syrian variant, Atargatis, see Catullus 63; Lucr. 2.614-623; Apul. Met. 8.27-28; Luc. Syr. D. 49-51; Luc. Dial D. 12.1; Aretaios 3.6.11; Tert. Apul. 25, with Frazer 1907: 221-227.

29) Luc. Syr. D. 51.

30) Frazer 1907: 223. 
addressed to Baal, see also Hos. 7:14, invocation to Yahweh or some other gods, possibly including Baal once again $)^{31}$.

The association between the practice of the Karians' in Egypt and the rituals devoted to Attis and Kybele turns even weaker by considering the fact there are no ancient references to bloody performances in these gods' cult for the Archaic and early Classical age. Moreover, it should be noticeable that although Ates is an ancient widespread Phrygian name, being attested even in three inscriptions associated to the monuments dedicated to the Great Phrygian Mother ${ }^{32}$, as the name of dedicants, the first representations of Attis as the attendant of the goddess appeared only in the $4^{\text {th }}$ century B.C. ${ }^{33}$.

It is not just the cult of Attis that seems to be a latter addition to the cult of the Phrygian Mother. It is likely that some other cultic elements, such as the processions performed with noisy songs, were later additions $^{34}$ to the original cult dedicated to an Anatolian goddess whose initial main attribute was that of embodiment of the force of nature.

Thus, even though the adoration and celebration of the Phrygian Mother is attested in Karia at the end of the Archaic age and the beginning of the Classical age, both in literary and archaeological sources $^{35}$, there are no grounds to admit the hypothesis that the custom observed by the Karians in Egypt during the festival dedicated at Busiris to Osiris originated in Anatolia, in the religious environment associated to Kybele - the Great Mother.

Maybe surprisingly for classicists, the mourning rituals performed by the Ugaritic gods El and Anat at the death of Baal are closer to the practice described by Herodotos. Their repertoire is very large, starting with their descending to the earth, the placing of dust on their heads and putting sackcloth on themselves, and culminating with making cuts with razors and knives on their cheeks, their chins, their chests and arms ${ }^{36}$. A shorter Ugaritic reference to the wounds inflicted on themselves by men mourners is provided in Aqht's cycle as well - at his funerals, some men lacerated themselves in order to express their grief, without any specifications about the exact manner of how they did $i^{37}$.

It is justified to imagine that in the Late Bronze Age, these practices were not confined solely to Ugarit $^{38}$. We may presume, on the ground of the prominent cultural and religious similarities between Ugarit and Canaan, that the Canaanites were making as well lacerations on their skin in order to express their grief at funerals.

The presumption is all the more well founded when taking into account that in the first millennium B.C. we see how the Jewish laws forbade such manner of expressing grief, alongside other similar customs as the shaving of the cranial hair (Deut. 14:1; Lev. 19:27-28; Lev. 21:5).

Nonetheless, these normative prescriptions against something that seems to be a cultural reminiscence from the Late Bronze Age West Semitic cultural area were not observed throughout the first half of the first millennium B.C. In the first half of the $6^{\text {th }}$ century B.C., Jeremiah, the prophet of the fall of Jerusalem refers to the gashing of the skin as to something quite common in the kingdom of Judah, his account bearing no proof of disapproval. Among other mourning practices, such as putting the sackcloth on oneself, rolling through ashes, singing dirges and cutting the hair (Jer. 4:8, 6:26; 7:29) ${ }^{39}$, Jeremiah foresaw also the following in his prophecy in 16:5-7, referring to the destruction of the Judahites:

31) Even though it might have had the same origin in the idea of the communion blood, as well as hair, is able of realising between the dead and the living and between human communities and the gods they worshipped - Smith 1894: 320-338. The difference between the two manifestations in the Semitic area is noticed also and explained in Schmidt 1994: 172-173.

32) Roller 1999: 70.

33) Roller 1999: 181-182. According to Roller 1999: 5, the myth of Attis might have been just a late Classical and Hellenistic invention added to the old Anatolian cult. The idea is supported by the low number of references to his cult in Asia Minor, compared to those in Greece and Rome - Roller 1999: 212. Even though there is a good possibility that the cult of the Phrygian Mother comprised also some funerary aspects celebrating the death of a legendary king called Attis, see Roller 1999: 252, there are no indications that among them there was the slashing of one's forehead, too.

34) Roller 1999: 169-177, especially 172-174, on the musical influences the cult of the Kretan goddess Rhea, interpreted by the Greeks as the Great Anatolian Mother, would have brought in the iconography and the religious practices of the latter.

35) Polyainos 8.53.4; Kiz1l 2007 on the stepped rock altars of Karia.

36) $K T U$ 1.5.vi-1.6.i. Laceration of face and upper body in $K T U$ 1.5.vi: 17b-20a și 1.6.i: 1-3a

37) $K T U$ 1.19.iv: 11, 22.

38) The story of "The Just Sufferer", that recalls "the brothers bathed with their blood" (RS 25.460, r. 11), although discovered in Ugarit, too, is written in Akkadian and may be considered as attesting that the custom was also spread in eastern Syria in the Late Bronze Age, in the area between Aleppo and Mari - Schmidt 1994: 168, 172-173.

39) Jews were also placing dust or earth on their head as a mourning custom - Jastrow 1899. 
Both high and low will die in this land. They will not be buried or mourned, and no one will cut themselves or shave their head for the dead. (Jer. 16:6) ${ }^{40}$.

This funerary practice is not confined only to Judah. After Nebuchadnezzar II conquered Jerusalem, he left Gedaliah as governor, who was killed through treachery by a conspirator. Immediately after the murder, the killer had to slaughter another eighty men "with their beards shaved off and their clothes torn and their bodies gashed", which were travelling from Schechem, from Shiloh and from Samaria, places in the kingdom of Israel, to the governor's residence in order to bring gifts to the house of the Lord (Jer. 41:4-5).

To the east, in the kingdom of Moab, cutting oneself seems to have been a common funerary practice as well. The same Jeremiah prophesizes the destruction of Moab as follows:

Every head is shaved and every beard cut off; every hand is slashed and every waist is covered with sackcloth. On all the roofs in Moab and in the public squares there is nothing but mourning, for I have broken Moab like a jar that no one wants, declares the Lord. (Jer. 48:37-38)

Unfortunately, the evidence for the funerary practices of the Phoenicians, the main successors of the Ugaritic civilization is scarce ${ }^{41}$ and the length to which the customs described in the cycles of Baal and Aqht were later perpetuated in the Iron Age cannot be verified $^{42}$. We might infer in a purely speculative manner that if in the southern Levant, occupied by Jews, cutting oneself was maintained, being adopted even by the conquerors, then it resisted also in the northern Levant. Fragments such as 1
Kings 18:28, mentioned above, demonstrate that in Judah and Israel the priests and worshipers of Baal and Astarte, divinities venerated by the Iron Age Phoenicians, were the main promoters of rituals closely related to those described in the Ugaritic texts.

We may conclude that while in Egypt and the Aegean-Anatolian area slashing the forehead is not attested as a custom, either in private funerary contexts or in public religious festivals of mourning, in the West Semitic cultural area it had already a long tradition going back in time at least to the Late Bronze Age ${ }^{43}$. At the end of the $7^{\text {th }}$ century B.C. and the beginning of the $6^{\text {th }}$ century B.C., cutting oneself in order to express grief and attachment to the deceased was a common practice, at least in the southern Levant, although it is highly probable that it rested in place in the northern Levant as well and some instances of it were present also in Mesopotamia, thus covering the whole Semitic area ${ }^{44}$.

\section{THE CUSTOM DIFFUSION AMONG THE KARIANS IN EGYPT}

The existence of innumerable parallels between Aegean and Oriental, particularly Semitic cultural items, habits and ideas, is no longer a novelty. Present researches should focus more on finding the contexts and the vectors of the cultural diffusion than signalling the similarities between the two great cultural areas as something totally new and surprising $^{45}$.

With regard to the particular funerary custom examined until now, we are not in the position to operate with certainties, due to the precarious characteristics of the existing sources. While we cannot

40) Schmidt 1994: 167 shows this is the dominant interpretation of the modern scholarship. On the other hand, accepting the literary and linguistic arguments for a later dating of the Deuteronomy and Leviticus, Schmidt proposes another reconstruction. Thus, Schmidt 1994: 176-178, 289-290 argues that cutting oneself as a funerary ritual was perceived as a common custom among both the Canaanites and the Jews in the pre-exilic and exilic periods. The interdictions in Deut. 14:1 and Lev. 19:27-28, $21: 5$ would have been introduced only later, not due to the Canaanite origin of the custom, but on account of the intention to clearly make a distinction between the worlds of the dead and the living. The intention itself was determined by the political evolutions of the Jewish society. For this study, the historical evolution of the banishment is less important that the fact both reconstructions prove that: 1 . the custom is specific to the West Semitic area, having origins in the Bronze Age; 2 . the Jews were observing it, as being a natural practice in the pre-exilic and exilic periods.

41) Dixon 2013

42) There are no proofs in this regard at the moment - Schmidt 1994: 174.

43) The same opinion is expressed concerning the rolling through ashes by Jastrow 1899: 149-150.

44) There is evidence for the performing of the practice in the $6^{\text {th }}$ century B.C. in Babylon, too - Nabonidus HI B, III.18-34, in Gadd 1958: 52-53, with Hays 2011: 40 - though we are not able to conclude if there was a local tradition of cutting oneself in Mesopotamia or the instances of this type of laceration are the consequence of West Semitic influence. Contradicting opinions in Finet 1987: 186 n. 21 and Schmidt 1994: 174-176, in my opinion, I consider that the Mesopotamian custom at the middle of the first millenium B.C. had West Semitic roots, being brought there some time before. Although it is highly probable that some Karian soldiers were engaged in the Babylonian and Persian armies - Pedersen 2005: 270; Waerzeggers 2006 - we know too little of them in order to surmise the Karians took the custom in Babylonia. Moreover, such a hypothesis would not resist to some chronological objections.

45) Cf. Raaflaub 2004: 200. 
finally dismiss even the Aegean-Anatolian origin of the practice, given the poor knowledge of the funerary and religious rituals of the region, we are even less able to firmly reject an eventual slow diffusion of the custom to the west, through the north Levantine and neo-Hittite states. As a matter of fact, it will be totally unwise to ignore obvious precedents like the adaptation of alphabet, from the West Semitic cultural area in northern Syria, in the Aegean.

On the other hand, applying the same diffusion model to cultural practices as different as writing and mourning rituals would be a methodological error. Personally, I do not think that slashing the foreheads could have been taken by the Karians in the same commercial milieu where the Greek merchants learnt the ways of writing from their Phoenician business partners.

From my point of view, it is highly plausible that the diffusion of the practice described by Herodotos and figured on the funerary stelai of Saqqara and Abusir took place only in Egypt among the Karians, while they were serving as mercenaries in the Saite army alongside Phoenician, Aramaic and Jewish soldiers.

The first indication in this direction is provided by the same Jeremiah, whose forced exile in Egypt gave him the opportunity to note some information on the Hebrew communities living in the Saite kingdom around 585 B.C. Thus, he mentions the communities living in Migdol, Tahpanhes, Nof (Memphis) and the Land of Patros (the Upper Egypt ${ }^{46}$. Especially in the case of the first three settlements it is known or it is thought with a great degree of certainty that they received or were frequently visited by Aegean mercenaries - Ionians and Karians ${ }^{47}$.

There are also other instances showing the proximity of the Semitic and Aegean mercenaries. They took part together to the Nubian campaign of Psam- metichos II in 593 B.C. as several Greek, Karian and Semitic (Phoenician) graffiti inscribed on the legs of the great statues of Abu Simbel demonstrate ${ }^{48}$. The graffiti also show that the mercenaries were grouped together in the Saite army, in the corps of those "of another language" 49 . Even though there are not any epigraphic testimonies, it might be possible that Jews mercenaries took part to the campaign, too ${ }^{50}$.

The close relation between the mercenary contingents might be infered also from the common participation of Aegean $(H 3 w-n b w)$ and Asiatic ('3mw- and Sttyw-, most probably Jews and Aramaeans from Syria) warriors from the garrison in Elephantine/Syene to a revolt against their Egyptian employers, event attested by a statue dedicated by Nesuhor, the dignitary who suppressed it ${ }^{51}$.

Furthermore we know that in Memphis, close to the Greek and Karian quarters ${ }^{52}$ there was also a Tyrian camp (Hdt. 2.112.2), where a sanctuary was built to the Stranger Aphrodite, most probably Astarte, despite Herodotos' identification with Helen of Troy ${ }^{53}$.

We may return to the information provided by Jeremiah. For him, mercenary forces were one of the best known characteristics of the Saite Egypt, a distinctive feature that he mentions in the destruction prophecy of the country:

The mercenaries in her ranks are like fattened calves. They too will turn and flee together; they will not stand their ground, for the day of disaster is coming upon them, the time for them to be punished. (Jer. 46:21)

Consequently, Jeremiah had detailed knowledge not only of the Jewish communities in Egypt, but of the mercenaries employed by the Saites, as well, of whom a part was recruited among the Jews.

46) See also Porten 1968: 7-16.

47) Oren 1984: 35-38. Recent evidence of the Aramaic and Phoenician presence in Memphis - "a multicultural metropolis of the ancient world" - close to the Greeks and Karians, in Dušek and Mynářová 2013 (quote at p. 53).

48) For the Greek graffiti (ML 7 a-g), Bernand and Masson 1957: 2-20; for the Karian (E.As 1-9), Adiego 2007: 115-118; for the Phoenician (CIS I 112 a-d), Schmitz 2010.

49) $M L$ 7a, cf. Hdt. 2.154.4. Lloyd 1975: 21-22; Haider 2001: 204, 211, fig. 6.

50) See Ps.-Aristeas' letter, Hellenistic document composed in order to ideologically support the Jewish community in the Ptolemaic Egypt, that casually alludes to the help provided by the Jews to an unspecified pharaoh Psammetichos during a campaign against the Ethiopians (Ps.-Aristeas 13). The campaign was identified by most researchers with that of 593 B.C., although others dispute this interpretation and associate the reference with supposed campaigns of Psammetichos I against Nubia - Kahn 2007.

51) Louvre 90 A, with Maspero 1884: 87-90, Schäffer 1904, Porten 1968: 14-16. The Jewish presence in Elephantine is recorded also in the Persian period in a collection of Aramaic papyri, for whom see Porten 1968 and Porten et al. 1996.

52) Aristagoras of Miletos FGrHist 608 F9 = Steph. Byz. s.v. Hellenikon kai Karikon; Steph. Byz. s.v. Karikon.

53) See Austin 1970: 28-29; Kaplan 2015: 400-401. Another possible context of cooperation and interaction between Aegeans and Semites in the Saite kingdom is that of the military fleet. There are proofs that both Phoenicians (Hdt. 4.42) and Greeks (ML 7a; Hdt. 2.154.5) had significant attributes in the Egyptian naval forces. Karians also might have served in the navy, see the vessel depicted on a Karian funerary stela in Lausanne - Lausanne 4727, with Masson and Yoyotte 1956: 20-27. 
Furthermore, Jeremiah gives evidence on the hybridization of the Jews living in Egypt, who had adopted religious beliefs and practices of the coinhabiting populations. He accuses the Jews, in the prophecy of their particular destruction, that they worship at the same time other gods of Egypt and the Queen of Heaven (Jer. 44:8, Jer. 44:15-19), most likely a feminine deity of Syrian origins ${ }^{54}$.

The image of a multicultural Egypt, where strangers deployed to key strategic settlements and the capital Memphis had innumerable opportunities to interact with each other, and with the locals, too, may be unmistakably drawn ${ }^{55}$. In what we are concerned, we must note, on the one hand, the rather strong association between mercenaries with different origins, but enjoying probably the same distinctive status in the Saite society, and, on the other hand, the diffusion of religious beliefs and practices from a community to another and even from an individual to another ${ }^{56}$.

\section{CONCLUSION}

A multicultural environment such as that which evolved in the Saite Egypt is the most favourable context where the diffusion of the funerary custom of slashing one's forehead, from its West Semitic practitioners to the Karians, might have taken place.

It is unlikely that someday we will have precise details of the way the Karians started to gash themselves in this context, imitating Jews, Aramaeans or Phoenicians. Nonetheless, we can imagine lots of moments, during military campaigns or the cohabitation in garrisons and quarters like those in Memphis or southern and eastern Egypt, when the Aegean mercenaries had the chance to assist and even to take part to Semitic funerals. We can imagine as well funerals where comrades of different stock, united however after facing together various perils and hardships, kept their unity also in mourning the fallen. Besides speculations such as these ones, we have in the end only the result attested in the stelai of Saqqara and Abusir and in the inquiries of Herodotos.

The particular case of the Karians in Egypt and their religious customs provides at the same time a good occasion to reflect over what hybridization is and its ways of manifestation. The situation described in Hdt. 2.61.2 displays Aegean mercenaries, taking part to an Egyptian religious festival, performing rituals most frequently found in the West Semitic area. On the other hand, some of the Karian stelai found around Memphis show the typically Aegean prothesis scene, alongside particular Egyptian motives ${ }^{57}$, while the Ionian and Karian mercenaries are shown in Hdt. 3.11 sealing an oath in a manner of obscure origin, probably a singular, original development of an Aegean-Anatolian custom, otherwise having parallels in the whole ancient world ${ }^{58}$. Manifesting elements of identity is always a matter determined by context, when the subjects choose from a wider or narrower series of cultural practices and markers, depending on their own experiences, those they consider the most appropriate.

This observation should be kept in mind every time someone studies the Greek and Karian mercenaries' activities in the East, in the Archaic age. It also highlights the need for modern researchers interested in the topic of Aegean mercenaries to develop their knowledge way further their initial formations as classical philologists and archaeologists, egyptologists or assyriologists in order to follow a true vocation of students of the ancient Eastern Mediterranean civilization.

L.M.I.

54) Bhagwan 2011 presumes that the Queen of Heaven of the Bible is a deity resulted through the mixture of atributes specific to several similar Semitic goddesses - Astarte/'A Ashtart, Ištar, Tanit şi Asherah. Elements of their cult are considered as inspiring some religious practices dedicated to Kybele, so there may be no surprise if the aforementioned bloody rituals devoted to the Great Mother had West Semitic roots, just like the custom investigated in the present study. In any case, the Aramaic influence over the Jews of Elephantine was quite strong, as shown by the papyri of the $5^{\text {th }}$ century - Porten 1968: 16-19.

55) To the point of mixed marriages, both between Aegeans and Egyptians (Austin 1970: 28-29; Moyer 2011: 55, n. 44, Kaplan 2015: 409), and between Asiatics and Egyptians (examples mainly from the Persian period, such as that of Artam and Tanofrether, who had Djedherbes as offspring - Mathieson et al. 1995).

56) Alongside the fragments from the book of Jeremiah, there might be mentioned the typical Egyptian scenes on some of the funerary stelai discovered at Saqqara - Masson 1978: 5; Martin and Nicholls 1978: 57-87 - as well as the typical Egyptian burial of Wahibre-em-achet, son of Alexicles and Zenodote (Leiden AM4 sarcophagus, with Grallert 2001). See also Kaplan 2015: 407-409.

57) Besides the already mentioned BM 67235 and Berlin ÄM 19553 (24139), we may count here the stelai Saqqara H5 - 1228 and Cairo JdE 91340.

58) Iancu 2015. 


\section{BIBLIOGRAPHY}

Agut-Labordère, D., 2012: "Plus que des mercenaires! L'intégration des hommes de guerre grecs au service de la monarchie saïte", Pallas 89: 293-306.

Adiego, I.J., 2007: The Carian Language, Leiden Boston.

Arslan, N. and K1z1l, A., 2007: "A Late Geometric Carian Grave from Beçin”, Anatolia Antiqua XV: 83-93. Andrews, M.L.E., 2010: An Exegesis of Leviticus 19.26-28. Diss. Lynchburg, VA.

Austin, M.M., 1970: Greece and Egypt in the Archaic Age, Cambridge.

Ballesteros Pastor, L., 2003: "El culto de Mitrídates a Zeus Estratio", in Garrido-Hory, M. and Gonzales, A. (eds.), Histoire, espaces et marges de l'Antiquité : hommages à Monique Clavel-Lévêque, vol. 2, Besançon: 209-222.

Bernand, A. and Masson, O., 1957: "Les inscriptions grecques d'Abou-Simbel', REG 70: 1-46.

Bhagwan, J.S., 2011: Queens of Heaven and Earth: Women and Goddess Worship in Pre-Exile Israel and Judah, Diss. Fiji.

Bryce, T., 1986: The Lycians in Literary and Epigraphic Sources, Copenhagen.

Carstens, A.M., 2008: "Tombs of the Halikarnassos peninsula: The Late Bronze and Early Iron Age", in Pedersen, P. (ed.), Halicarnassian Studies, vol. V, Odense: 52-118.

Cumont, F., 1896: “Attis”, RE 2, pt. 2: 2247-52.

Dale, L., 2015: Responses to Self Harm: An Historical Analysis of Medical, Religious, Military and Psychological Perspectives, Jefferson, North Carolina.

Daryaee, T. and Malekzadeh, S., 2014: "The Performance of Pain and Remembrance in Late Antique Iran", The Silk Road 12: 57-64.

Dixon, H.M., 2013: Phoenician Mortuary Practice in the Iron Age I-III (ca. 1200-ca. 300 BCE) Levantine "Homeland", Diss. University of Michigan.

Dušek, J. and Mynářová, J. 2013: "Phoenician and Aramaic Inscriptions from Abusir", in Botta, A. (ed.), In the Shadow of Bezalel. Aramaic, Biblical, and Ancient Near Eastern Studies in Honor of Bezalel Porten, Leiden - Boston: 53-69.

Emery, W.B., 1970: "Preliminary Report on the Excavations at North Saqqâra, 1968-9”, JEA 56: 5-11.

- 1971: "Preliminary Report on the Excavations at North Saqqâra, 1969-70”, JEA 57: 3-13.

Finet, A., 1987: "Usages et rites funeraires en Babylonie", in Laffineur, R. (ed.), Thanatos. Les coutumes funéraires en Egée à l'âge du Bronze. Actes du colloque de Liège, 21-23 avril 1986, Aegeum 1, Liège - Austin: 235-244.

Frazer, J.G., 1907: Adonis, Attis, Osiris. Studies in the History of Oriental Ancient Religion, ed. II, London.

Gadd, J.C., 1958: "The Harran Inscriptions of Nabonidus", Anatolian Studies 8: 35-92.
Grallert, S., 2001: “Akkulturation im agyptischen Sepulkralwesen: der Fall eines Griechen in Ägypten zur Zeit der 26. Dynastie", in Hockmann, U. and Kreikenbom, D. (eds.), Naukratis: Die Beziehungen zu Ostgriechenland, Ägypten und Zypern in archaischer Zeit, Möhnsee: 182195.

Haider, P.W., 2001: "Epigraphische Quellen zur Integration von Griechen in die ägyptische Gesellschaft der Saïtenzeit", in Hockmann, U. and Kreikenbom, D. (eds.), Naukratis: Die Beziehungen zu Ostgriechenland, Ägypten und Zypern in archaischer Zeit, Möhnsee: 197215.

Haland, E.J., 2014: Rituals of Death and Dying in Modern and Ancient Greece. Writing History from a Female Perspective, Newcastle-upon-Tyne.

Hartog. F., 1988: The Mirror of Herodotos: The Representation of the Other in the Writing of History, trans. J. Lloyd, Berkeley, CA.

Hays, C., 2011: Death in the Iron Age II and in First Isaiah, Tübingen.

Henry, O. 2009: Tombes de Carie: Architecture funéraire et culture Carienne $V I^{e}-I I^{e}$ siècle av. J.-C., Rennes.

Herda, A., 2010: "Greek (and our) Views on the Karians", in Mouton, A., Rutherford, I. and Yakubovich, I. (eds.), Luwian Identities. Culture, Language and Religion Between Anatolia and the Aegean, Leiden: 421-506.

How, W.W. and Wells, J., 1912: A Commentary on Herodotos, 2 vols, Oxford.

Hoz Bravo, J. de, 2010: “Aspects de l'écriture des migrants : le cas des Cariens d'Egypte", in Rouillard, P. (ed.), Portraits de migrants, portraits de colons II, Paris: 229-237.

Iancu, L. 2015: "Hdt. 3.11 - Punishment, Human Sacrifice, Oath, Symposion? Ritual and Group Cohesion”, CICSA Journal 1: 28-40.

Jastrow, M. 1899: "Dust, Earth and Ashes as Symbols of Mourning among the Ancient Hebrews", JAOS 20: 133-150.

Kahn, D. 2007: “Judean Auxiliaries in Egypt's Wars against Kush”, JAOS 127: 507-516.

Kammerzell, F., 1993: Studien zu Sprache und Geschichte der Karer in Ägypten, Wiesbaden.

Kaplan, P., 2002: "The Social Status of the Mercenary in the Archaic Age", in Gorman, V. and Robinson, E. (eds.), Oikistes. Studies in Constitutions, Colonies, and Military Power in the Ancient World. Offered in Honor of A.J. Graham, Leiden - Boston - Köln: 229-243.

- 2015: "Sojourner in the Land: The Resident Alien in Late Period Egypt", in Harrison, T.P. and Banning E.B. (eds.), Walls of the Prince: Egyptian Interactions with Southwest Asia in Antiquity, Leiden: 396-413.

K1z1l, A., 2007: “An Open Air Stepped Rock Altar at Kalem Köy in Milas, Karia”, Anodos 6-7: 233-239.

Laumonier, A., 1958: Les Cultes indigènes en Carie, Paris. 
Lloyd, A.B., 1975: Herodotos, Book II. Introduction, Leiden. den.

- 1976: Herodotos, Book II. Commentary 1-98, Lei-

- 1988: Herodotos, Book II. Commentary 99-182, Leiden.

- 2007: "Book II", in Murray, O. and Moreno, A. (eds.), A Commentary on Herodotos Book I-IV, Oxford: 219-378.

Martin, G.T. and Nicholls, R.V., 1978: "Hieroglyphic stelae with Carian texts and Carian stelae with Egyptianizing or Hellenizing motifs", in Masson, O., Carian Inscriptions from North Saqqara and Buhen, London: 55-87.

Maspero, G. 1884: "Notes sur quelques points de grammaire et d'histoire", Z̈̈S 22: 78-93.

Masson, O., 1978: Carian Inscriptions from North Saqqara and Buhen, London.

Masson, O. and Yoyotte, J., 1956: Objets pharaoniques à inscriptions cariennes, Cairo.

Mathieson I.J. et al., 1995: "A Stela of the Persian Period from Saqqara", JEA 81: 23-41.

McAnally, J., 2016: "Herodotos 2.61.2 and the $M w$ don- of Caromemphitae", ANES 53: 171-194.

Miller, M.C., 1997: Athens and Persia in the fifth century B.C.: a study in cultural receptivity, Cambridge. Moyer. I., 2011: Egypt and the Limits of Hellenism, New York.

Olyan, S., 2004: Biblical Mourning. Ritual and Social Dimensions, New York, Oxford University Press, 2004. - 2012: "Theorizing Violence in Biblical Ritual Contexts: The Case of Mourning Rites", in Olyan, S. (ed.), Social Theory and the Study of Israelite Religion. Essays in Retrospect and Prospect, Atlanta: 169-80.

Oren, E., 1984: "Migdol: A New Fortress on the edge of the Eastern Nile Delta", BASOR 256: 7-44.

Pedersen, O., 2005: "Foreign Professionals in Babylon: Evidence from the Archive in the Palace of Nebuchadnezzar II", in van Soldt, W. et al. (eds.), Ethnicity in Ancient Mesopotamia, Leiden: 267-272.

Porten, B., 1968: Archives from Elephantine: The Life of an Ancient Jewish Military Colony, Berkeley.

Porten, B. et al., 1996: The Elephantine papyri in English: Three millennia of cross-cultural continuity and change, Leiden.
Quirke, S., 2015: Exploring Religion in Ancient Egypt, Chichester.

Raaflaub, K., 2004: "Archaic Greek Aristocrats as Carriers of Cultural Interaction", in Rollinger, R. and Ulf, C. (eds.), Commerce and Monetary Systems in the Ancient World. Means of Transmission and Cultural Interaction. Proceedings of the Fifth Annual Symposium of the Assyrian and Babylonian Intellectual Heritage Project. Held in Innsbruck, Austria, October $3^{\text {rd }}-8^{\text {th }}$ 2002, Stuttgart: 197-217.

Roller, L.E., 1999: In Search of God the Mother: The Cult of Anatolian Cybele, Berkeley.

Schäfer, H., 1904: "Die Auswanderung der Krieger unter Psammetich I. und den Söldner-Aufstand in Elephantine unter Apries", Klio 4, 152-163.

Schmidt, B., 1994: Israel's Beneficent Dead: Ancestor Cult and Necromancy in Ancient Israelite Religion and Tradition, Tübingen.

Schmitz, P., 2010: "The Phoenician Contingent in the Campaign of Psammetichus II Against Kush", JEGH 3: 321-337.

Smith, W.R., 1894: Lectures on the Religion of the Semites, London.

Snape, S., 2011: Ancient Egyptian Tombs: The Culture of Life and Death, Chichester.

Strathmann, H., 1950: "Attis", RAC 1: 889-899.

Vignolo Munson, R., 2001: Telling Wonders: Ethnographic and Political Discourse in the Work of Herodotos, Ann Arbor.

Vittmann, G., 2003: Ägypten und die Fremden im ersten vorchristlichen Jahrtausend, Mainz.

Waerzeggers, C., 2006: "The Carians of Borsippa", Iraq 68, 1-22.

van Wees, H., 1988: “A brief history of tears: Gender differentiation in archaic Greece", in Foxhall, L. and Salmon, J. (eds.), When Men Were Men. Masculinity, power and identity in classical antiquity, London - New York: 10-53.

- 2013: Ships and silver, taxes and tribute. A fiscal history of archaic Athens, London. 